Article

\title{
The Missing Piece in Biosynthesis of Amphidinols: First Evidence of Glycolate as a Starter Unit in New Polyketides from Amphidinium carterae
}

\author{
Adele Cutignano *, Genoveffa Nuzzo, Angela Sardo and Angelo Fontana \\ Institute of Biomolecular Chemistry, National Research Council (CNR), Pozzuoli 80078, Naples, Italy; \\ nuzzo.genoveffa@icb.cnr.it (G.N.); angela.sardo@icb.cnr.it (A.S.); angelo.fontana@icb.cnr.it (A.F.) \\ * Correspondence: adele.cutignano@icb.cnr.it; Tel.: +39-081-867-5313
}

Academic Editor: Paul Long

Received: 28 April 2017; Accepted: 25 May 2017; Published: 31 May 2017

\begin{abstract}
Two new members of the amphidinol family, amphidinol A (1) and its 7-sulfate derivative amphidinol B (2), were isolated from a strain of Amphidinium carterae of Lake Fusaro, near Naples (Italy), and chemically identified by spectroscopic and spectrometric methods. Amphidinol A showed antifungal activity against Candida albicans (MIC $=19 \mu \mathrm{g} / \mathrm{mL}$ ). Biosynthetic experiments with stable isotope-labelled acetate allowed defining the elongation process in $\mathbf{1}$. For the first time the use of glycolate as a starter unit in the polyketide biosynthesis of amphidinol metabolites was unambiguously demonstrated.
\end{abstract}

Keywords: amphidinol; amphidinol-related polyketide; Amphidinium; dinoflagellate, glycolate; polyketide biosynthesis; PKS; antifungal polyketide; Candida albicans; SHAM

\section{Introduction}

Marine microorganisms are an impressive source of secondary metabolites with complex chemical structures and remarkable biological properties [1]. In our ongoing search for novel marine bioactive molecules [2], we recently focused our attention on microorganisms from the Mediterranean region. In particular, from Lake Fusaro, near Naples (Italy), we isolated a dinoflagellate strain, which was taxonomically identified as Amphidinium carterae. The methanol extract of the new isolate displayed antifungal activity against Candida albicans $(\mathrm{MIC}=64 \mu \mathrm{g} / \mathrm{mL}$ ) and its preliminary chemical analysis revealed the occurrence of polyoxygenated polyketide compounds related to amphidinols, a family of long-chain polyhydroxy polyketides including polyene-amphidinols and other related metabolites [3-23]. They have been mostly reported from dinoflagellates of the genus Amphidinium and exhibited potent biological activities, including antifungal, cytotoxic, and hemolytic properties. From a chemical point of view, all of the members of the family contain a core of two tetrahydropyrans linked by a C6 alkyl chain. One of the most intriguing aspects of these natural products is the biosynthetic assembly of the polyketide chain. Studies reported so far clarify the diverse and peculiar acetate incorporation pattern, leaving unsolved the question about the starter unit, not labelled by this precursor. In analogy with biosynthesis of okadaic acid and congeners [24] glycolate was suggested as a candidate precursor, but no evidence has been provided to date. Here we describe the structural elucidation, biological activity, and the results of biosynthetic studies on two amphidinols from the newly-isolated strain of $A$. carterae.

\section{Results and Discussion}

The marine microalgal strain was isolated from seaweed samples collected at Lake Fusaro, near Naples (Italy) in June 2012. The culture was grown in $8 \times 1.8 \mathrm{~L}$ Fernbach bottles for two weeks. The cell 
pellet was extracted with methanol and the resulting organic extract was fractionated by a Chromabond Hydra C-18 cartridge using a $\mathrm{MeOH} / \mathrm{H}_{2} \mathrm{O}$ gradient according to our reported procedure [21]. Further purification by reversed phase HPLC gave pure compounds $\mathbf{1}(1.6 \mathrm{mg})$ and $\mathbf{2}(1.0 \mathrm{mg})$ (Figure 1). HRESIMS of the molecular ion (sodium adduct) of 1 at $m / z 1361.8537$ accounted for the molecular formula $\mathrm{C}_{69} \mathrm{H}_{126} \mathrm{O}_{24}$. A comparison of ${ }^{1} \mathrm{H}$ NMR of polyketide 1 with AM18 (3) which we previously reported from a commercial strain of $A$. carterae [21], suggested strict structural analogies (Figure 1). Most of the signals were superimposable, with the main differences emerging only in the olefinic region of the spectrum due to the absence of conjugated double bonds in compound $\mathbf{1}$.

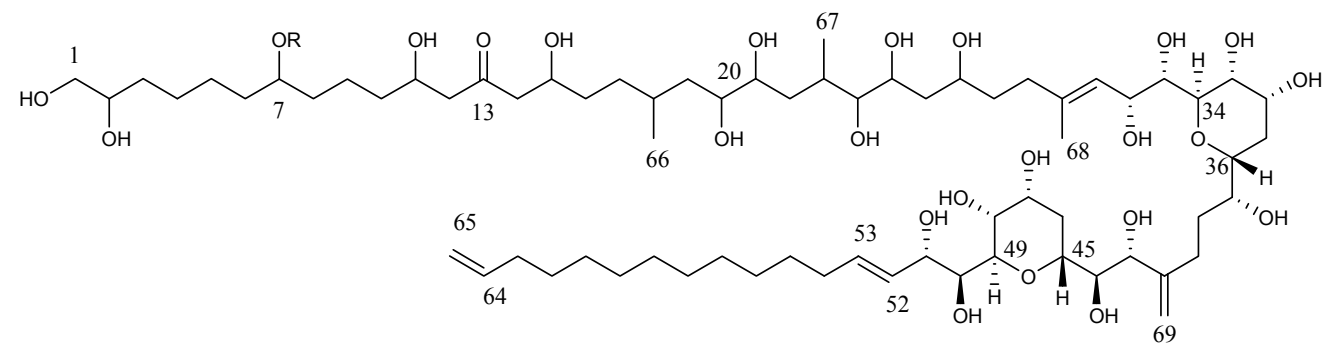

$\mathrm{R}=\mathrm{H} \quad$ Amphidinol A (1)

$\mathrm{R}=\mathrm{SO}_{3}{ }^{-}$Amphidinol B (2)

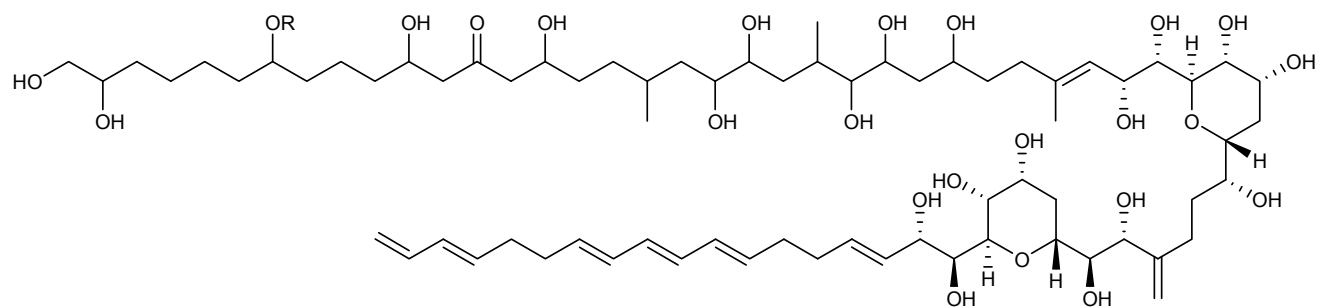

$\mathrm{R}=\mathrm{H} \quad$ Amphidinol $18(\mathbf{3}, \mathrm{AM} 18)$

$\mathrm{R}=\mathrm{SO}_{3}{ }^{-}$Amphidinol 19 (4, AM19)

Figure 1. Structures of amphidinols 1-4.

A careful inspection of mono- $\left({ }^{13} \mathrm{C}\right)$, homo-, and hetero-nuclear-bidimensional NMR data (Table 1 and Supplementary Materials) allowed identifying in the molecular skeleton of the isolated metabolite 1 the same substructure C1-C53 of 3, including the 7-hydroxyl group, the $\beta, \beta^{\prime}$-dihydroxyketone functionality at $\mathrm{C} 13$ and the typical bis-tetrahydropyrans core. These latter rings showed the same stereostructure described for 3, deduced by J couplings and nOe effects analysis, as depicted in Figure 2.
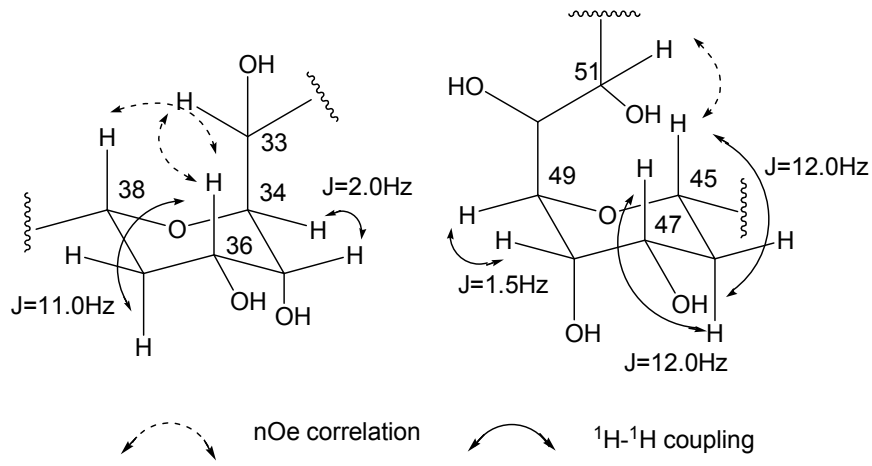

Figure 2. Relative configurations of the tetrahydropyran rings of amphidinol A (1). 
The structural similarities with AM18 (3) were confirmed by interpretation of the ESI-MS/MS spectrum of 1 registered on the molecular ion $[\mathrm{M}+\mathrm{Na}]^{+}$that contained the common fragments at $m / z 669.3810,687.3916,745.4333$, and 963.5837, as well as the fragment at $m / z 169.0466$, diagnostic for the assignment of the isolated hydroxyl function at position 7 (Figure S21). From the other side, a saturated alkyl chain (C54-C63) joined the olefinic carbon C53 (135.3 ppm; H53, 85.85$)$ to the terminal double bond (C64, 140.1 ppm; H64, $\delta 5.77$ and C65, 115.0 ppm; H65, $\delta 4.91,4.97)$. According to these observations, 1 differed from 3 in the structure of the aliphatic chain (C52-C65) which was shorter by two carbon atoms and did not contain the conjugated triene moiety in agreement with the seven degrees of formal unsaturations suggested by the molecular formula. The polyketide $\mathbf{1}$ represented a new member of the amphidinol family and, thus, is named amphidinol A (1). A terminal saturated alkyl chain is rather uncommon within this group of polyketides and has been so far described in few analogues isolated from Amphidinium sp., such as lingushiol [13], and karatungiols A and B [16]. Like congener AM18, amphidinol A inhibited the growth of C. albicans at $19 \mu \mathrm{g} / \mathrm{mL}$ (MIC), thus accounting for the antifungal properties of the extract.

Along with the microalgal metabolite 1, HPLC purification afforded its 7-sulfate derivative 2 (Figure 1). This latter metabolite was typically recognizable by both chemical shifts of the deshielded oxymethine signals at $C 7(80.3 \mathrm{ppm}, \delta 4.39)$ and the diagnostic sulfate product ions at $\mathrm{m} / z 96.9589$ $\left(\mathrm{HSO}_{4}{ }^{-}\right)$in MS / MS spectrum of its molecular ion at $m / z 1417.8187[\mathrm{M}-\mathrm{H}]^{-}$(Figure S22) and at 142.9386 $\left(\mathrm{HSO}_{4} \mathrm{Na}_{2}{ }^{+}\right.$) in the MS/MS spectrum of the sodium adduct $[\mathrm{M}-\mathrm{H}+2 \mathrm{Na}]^{+}$at $m / z 1463.7912$ (Figure S23). The sulfate ester 2 has never been reported before, and was then named amphidinol B. Compound 2 did not show activity against C. albicans when assayed up to $150 \mu \mathrm{g} / \mathrm{mL}$, thus confirming, as observed for AM19 (4), that sulfate substitution affects antifungal activity on these molecular skeletons [21].

Biosynthesis of marine polyketides from dinoflagellates is a stimulating field of study that has been hampered, so far, by a still-limited knowledge on the biochemistry and molecular genetics of these metabolites [25]. Furthermore, technical obstacles arose from intrinsic factors such as the slow growth rate of dinoflagellates, low levels of polyketide metabolites, and the scrambling of labelled carbons of precursors. In this scenario, very few studies have been reported in the literature addressing the biosynthesis of dinoflagellate polyketides, mostly focused on polyether toxins and macrolides [25], and only two research groups have performed studies on amphidinols by stable isotope feeding experiments $[6,11]$. According to this literature, the regular elongation by acetate units, as expected for a polyketide synthase (PKS) catalyzed process, is interrupted in a few sites by a Favorskii-type rearrangement, which involves $\mathrm{C} 1$ deletions and an atypical labelling pattern from the acetate precursor. This chemistry, although unusual, has been also reported in polyketides of bacteria [26,27], fungi [28], and in other dinoflagellates (i.e., in amphidinolides and polyether toxins) $[25,29]$. However, the identity of the biosynthetic starter unit, which was not labelled by acetate, was proposed as glycolate in amphidinols in analogy with other microalgal polyketides [23]. In order to shed light on this point and complete the picture of the biosynthetic assembly for this class of metabolites, we run a set of feeding experiments with labelled precursors, i.e., $\left[1-{ }^{13} \mathrm{C}\right]$-acetate, $\left[2-{ }^{13} \mathrm{C}\right]$-acetate, $\left[1,2-{ }^{13} \mathrm{C}_{2}\right]$-acetate, and $\left[1-{ }^{13} \mathrm{C}\right]$-glycolate to detect by ${ }^{13} \mathrm{C}$ NMR the carbon enrichments in the molecular skeleton of $\mathbf{1}$, the most abundant polyketide.

Carbon labelling by feeding experiments with ${ }^{13} \mathrm{C}$-acetate precursors, as depicted in Figure 3 revealed a basically regular chain elongation in the frame C3/C20. In fact, a single rearrangement was evidenced by the labelling of the methyl group at $21.3 \mathrm{ppm}$ (C66), resultantly enriched with $\left[2-{ }^{13} \mathrm{C}\right]$-acetate. Labelling from C21 to C53 was identical to that reported for AM4, which indeed shares the same substructure [6]. Thus, four sites of discontinuity were detected for the positions $\mathrm{C} 21 / \mathrm{C} 22, \mathrm{C} 30 / \mathrm{C} 31 / \mathrm{C} 68, \mathrm{C} 45 / \mathrm{C} 46$, and $\mathrm{C} 52 / \mathrm{C} 53$, which were all labelled by $\left[2-{ }^{13} \mathrm{C}\right]$-acetate, along with the pendant methyl group at $14.2 \mathrm{ppm}$ (C67) and the olefinic methylene at $113.0 \mathrm{ppm}$ (C69). Carbon signals of the terminal saturated arm C54-C63 could not be unambiguously assigned due to severe overlapping. However, five aliphatic signals in the segment C54-C63 resultantly increased by $\left[1-{ }^{13} \mathrm{C}\right]$-acetate at $29.9,30.2,30.5,30.7$, and $34.6 \mathrm{ppm}$, and five from $\left[2-{ }^{13} \mathrm{C}\right]$-acetate at $30.1,30.3,30.55$, 
30.8 , and $34.6 \mathrm{ppm}$. The experiment with doubly-labelled acetate confirmed a regular pattern due to intact $\mathrm{C}_{2}$-unit incorporation in this part, showing all of the aliphatic signals resonating as doublets flanking the natural isotopomer carbons (Figure S17). Furthermore, due to skeleton rearrangement and cleavage of the original $C_{2}$ unit, signals at 14.2 (C67), 17.4 (C68), 21.3 (C66), 70.6 (C45), 72.6 (C21), 113.0 (C69), and 129.1 (C52) ppm resonated as singlets. Additional information was inferred about the terminal double bond, whose signal at 140.1ppm (C64) resonated as a doublet $(J=22 \mathrm{~Hz})$ while methylene at $115.0 \mathrm{ppm}$ (C65) appeared as a singlet signal (Figure S17), possibly due to a terminal decarboxylation step. As expected, no labelling was observed for positions 1 and 2 of the polyketide chain.

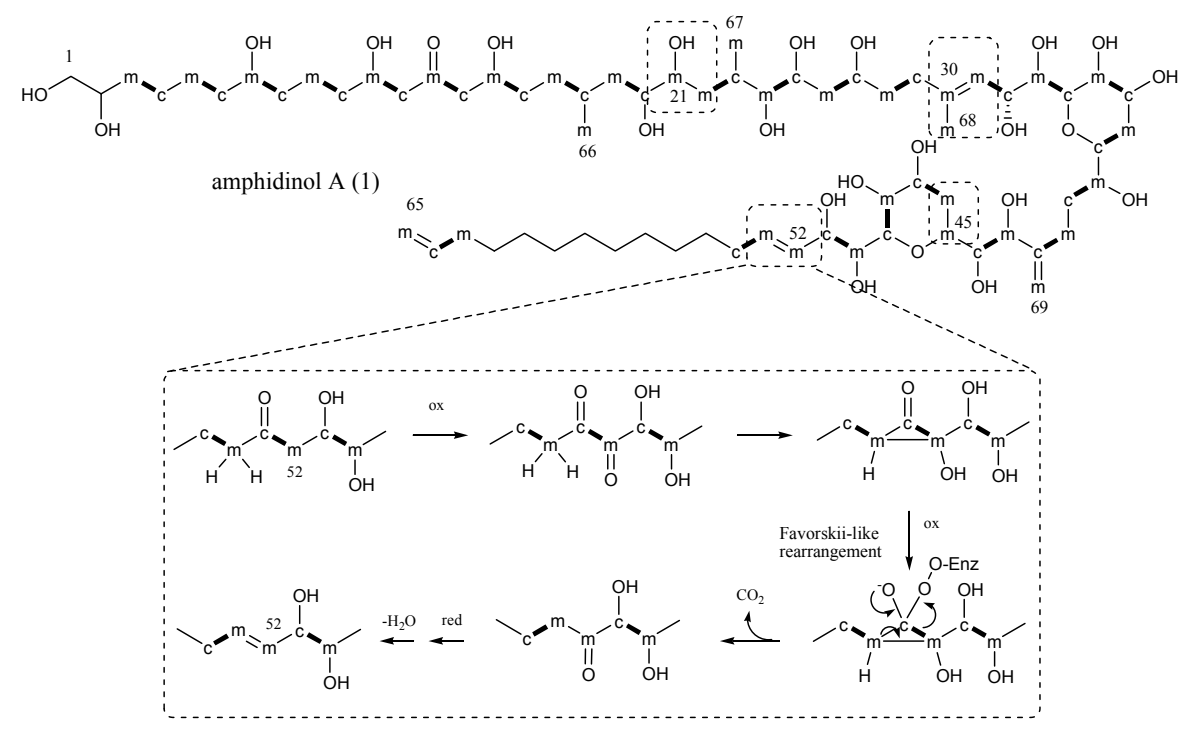

Figure 3. Acetate labelling pattern of amphidinol A (1). c: carbons labelled from $\left[1-{ }^{13} \mathrm{C}\right]$-acetate. $\mathrm{m}$ : carbons labelled from $\left[2-{ }^{13} \mathrm{C}\right]$ acetate. $\mathrm{c}-\mathrm{m}$ : incorporation of intact acetate unit from $\left[1,2-{ }^{13} \mathrm{C}_{2}\right]$-acetate. Discontinuous labelling is evidenced with the dashed boxes. The inset shows a proposed mechanism for a Favorskii-type rearrangement from [26].

On the other hand, HRESIMS analysis of 1 after the feeding experiment with $\left[1-{ }^{13} \mathrm{C}\right]$-glycolate revealed an isotopic cluster centered around $m / z 1375$ indicating a random incorporation of several labelled atoms in the molecule (Figure 4B).

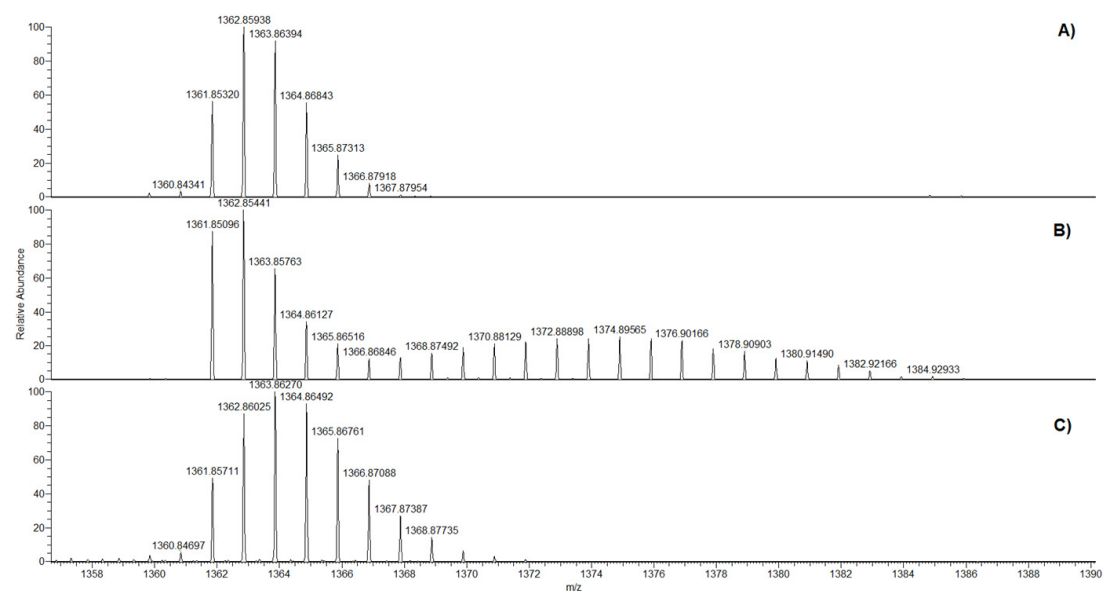

Figure 4. $\mathrm{HRESI}^{+}$-MS spectra of amphidinol A (1). (A) Natural abundance profile; (B) labelling after the $\left[1-{ }^{13} \mathrm{C}\right]$-glycolate feeding experiment; and (C) labelling after the $\left[1-{ }^{13} \mathrm{C}\right]$-glycolate/SHAM feeding experiment. 
As a confirmation, the ${ }^{13} \mathrm{C}$ NMR spectrum of 1 showed a general enrichment of every carbon together with the presence of flanking doublets for the statistically occurrence of two vicinal ${ }^{13} \mathrm{C}$ in the same skeleton (Figure S18). This multiple labelling was interpreted as the result of an oxidative pathway occurring on the glycolate substrate with the metabolic release via a glyoxylate intermediate of $\mathrm{CO}_{2}$, which may be recycled by microalgal photosynthetic processes in a very efficient way.

Glycolate is a product of photorespiration, one of the major carbon metabolism pathways in oxygen-producing photosynthetic organisms. This process, started by an oxygenase reaction of Rubisco, competes with photosynthetic $\mathrm{CO}_{2}$ fixation, causing a loss of carbon, nitrogen, and energy. Thus, a series of strategies have been developed by photosynthetic organisms to efficiently recycle glycolate and other undesired products of photorespiration. In higher plants and multicellular algae, glycolate is oxidized to glyoxylate by a glycolate oxidase in the peroxisomes [30]. In turn, glyoxylate is metabolized to glycine that, in mitochondria, by conversion into serine, releases $\mathrm{CO}_{2}$ and $\mathrm{NH}_{4}{ }^{+}$. Instead, in unicellular green algae, it has been described a major light-dependent glycolate oxidizing system mainly located in the chloroplasts and associated with the photosynthetic electron transport apparatus [31]. In these microorganisms glyoxylate is degraded to $\mathrm{CO}_{2}$, which can be recycled and fixed by photosynthetic machinery. The glycolate-oxidizing enzyme is specifically associated with a quinone oxidoreductase system and is inhibited by salicylhydroxamic acid (SHAM) without affecting $\mathrm{CO}_{2}$ fixation in intact cells [32]. Little is known on the glycolate metabolism in dinoflagellates, thus, our working hypothesis was that a similar putative oxido-reductase may be involved in glycolate oxidation in microalgal Amphidinium cells. Degradation of $\left[1-{ }^{13} \mathrm{C}\right]$-glycolate in A. carterae may afford labelled $\mathrm{CO}_{2}$ which is incorporated in primary metabolites, whose breakdown feeds the pool of acetyl-CoA, the building block of polyketides and, namely, of amphidinol A (1). Therefore, inhibition of the glycolate/glyoxylate transformation was expected to arrest fast glycolate catabolism, avoiding scrambling of the labelling from the $\left[1-{ }^{13} \mathrm{C}\right]$-glycolate precursor (Figure 5).

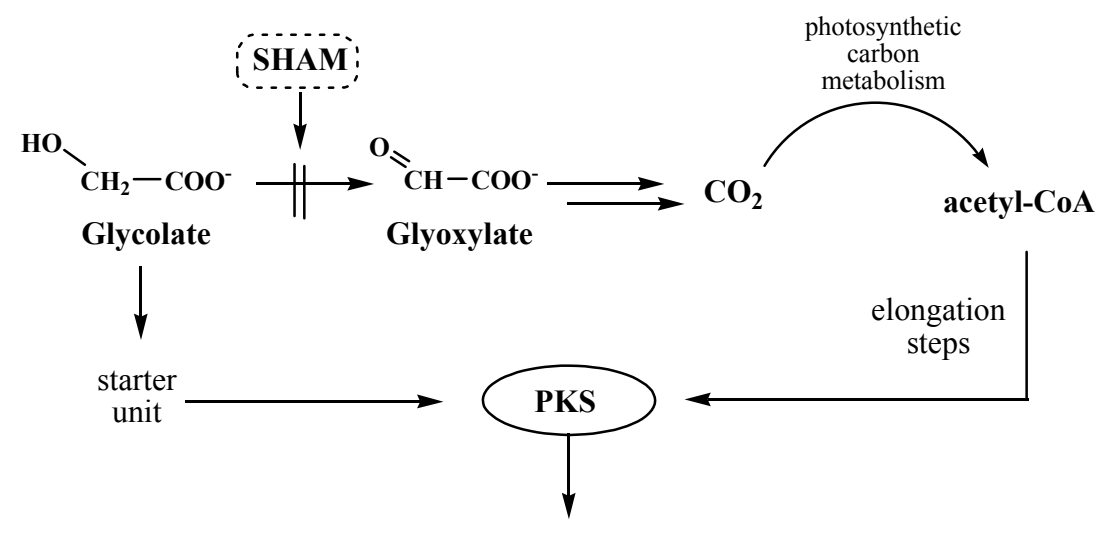

amphidinol A (1)

Figure 5. Proposed route of glycolate degradation via glyoxylate and cross-talking with biosynthesis of amphidinol A (1) in A. carterae. Inhibition of the oxidative pathway by SHAM stops recycling of glycolate carbon by photosynthetic metabolism, but does not affect polyketide biosynthesis by PKS.

Following this line of reasoning, we decided to co-administer $\left[1-{ }^{13} \mathrm{C}\right]$-glycolate and SHAM to cultures of $A$. carterae. Under the same conditions used for the other feeding experiments, extraction of microalgal cells gave amphidinol A (1) with a simplified enrichment pattern, as shown in Figure 4C. The carbon labelling appeared to be restricted to the incorporation of a single carbon, as suggested by $\mathrm{M}+1$ and $\mathrm{M}+2$ signal increases with respect to the mass spectrum of the unlabeled product. Accordingly, the ${ }^{13} \mathrm{C}$ NMR spectrum showed remarkable incorporation only in the signal at $73.1 \mathrm{ppm}$ assigned to C2 (Figure 6), as expected if $\left[1-{ }^{13} \mathrm{C}\right]$-glycolate is used as the starter unit.

In conclusion, we have identified two new members of the amphidinol family, here named amphidinol A (1) and amphidinol B (2), from a dinoflagellate strain of A. carterae isolated from 
Lake Fusaro, a brackish lagoon near Naples (Italy). Compound 1 showed a mild antifungal activity. Biosynthetic studies on amphidinol A were addressed with stable labelled acetate and glycolate and proved, for the first time, that glycolate is the starter unit of PKS assembly leading to this class of metabolites. This finding completes the characterization of the biogenesis of these complex microalgal polyketides that show several points of skeleton rearrangements and carbon deletions. Behind the aim of this work, the results of biosynthetic experiments with $\left[1-{ }^{13} \mathrm{C}\right]$-glycolate may have positive implications in the study of carbon metabolism in dinoflagellates.

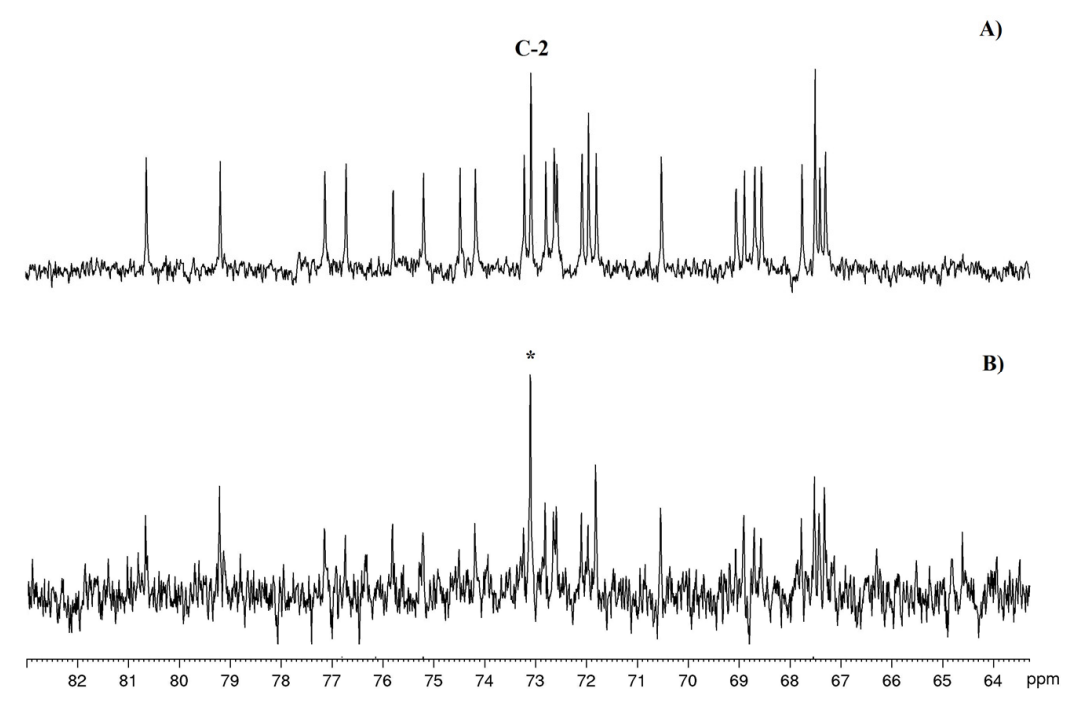

Figure 6. ${ }^{13} \mathrm{C}$ NMR spectra enlargements of 1. (A) Natural abundance; (B) after feeding experiment with $\left[1-{ }^{13} \mathrm{C}\right]$ glycolate/SHAM. $\left({ }^{*}\right)$ indicates labelled carbon. 
Table 1. NMR data (600 MHz) of amphidinol A (1) and B (2).

\begin{tabular}{|c|c|c|c|c|c|c|c|c|c|c|c|}
\hline \multirow{3}{*}{ Position } & \multirow{3}{*}{ Type } & \multicolumn{2}{|r|}{1} & \multicolumn{2}{|r|}{2} & \multirow{3}{*}{ Position } & \multirow{3}{*}{ Type } & \multicolumn{2}{|r|}{1} & \multicolumn{2}{|r|}{2} \\
\hline & & \multicolumn{2}{|c|}{$\mathrm{CD}_{3} \mathrm{OD} / \mathrm{C}_{5} \mathrm{~N}_{5} \mathrm{D}(2: 1)$} & \multicolumn{2}{|r|}{$\mathrm{CD}_{3} \mathrm{OD}$} & & & \multicolumn{2}{|c|}{$\mathrm{CD}_{3} \mathrm{OD} / \mathrm{C}_{5} \mathrm{~N}_{5} \mathrm{D}(2: 1)$} & \multicolumn{2}{|c|}{$\mathrm{CD}_{3} \mathrm{OD}$} \\
\hline & & $\delta_{\mathrm{C}}$ & $\delta_{\mathrm{H}}$, mult, $J(\mathrm{~Hz})$ & Type & $\delta_{\mathrm{H}}$, mult, $J(\mathrm{~Hz})$ & & & $\delta_{C}$ & $\delta_{\mathrm{H}}$, mult, $J(\mathrm{~Hz})$ & $\delta_{\mathrm{C}}$ & $\delta_{\mathrm{H}}$, mult, $J(\mathrm{~Hz})$ \\
\hline 1 & $\mathrm{CH}_{2}$ & 67.6 & $3.55, \mathrm{~m} ; 3.59, \mathrm{~m}$ & 67.1 & $\begin{array}{c}\text { 3.44, dd, } 11.0,6.3 ; \\
3.51, \mathrm{~m}\end{array}$ & 33 & $\mathrm{CH}$ & 72.7 & $3.87, \mathrm{dd}, 9.0,2.0$ & 72.4 & $3.70, \mathrm{~m}$ \\
\hline 2 & $\mathrm{CH}$ & 73.1 & $3.71, \mathrm{~m}$ & 73.0 & $3.61, \mathrm{~m}$ & 34 & $\mathrm{CH}$ & 79.2 & $4.26, \mathrm{dd}, 9.5,2.0$ & 79.1 & $3.99 \mathrm{~d}, \mathrm{~m}$ \\
\hline 3 & $\mathrm{CH}_{2}$ & 34.7 & $1.47, \mathrm{~m} ; 1.57, \mathrm{~m}$ & 34.2 & $1.41, \mathrm{~m}$ & 35 & $\mathrm{CH}$ & 69.0 & $4.34, \mathrm{~m}$ & 67.2 & $4.07, \mathrm{~m}$ \\
\hline 4 & $\mathrm{CH}_{2}$ & 26.8 & $1.40, \mathrm{~m} ; 1.46, \mathrm{~m}$ & 26.6 & $1.43, \mathrm{~m} ; 1.52, \mathrm{~m}$ & 36 & $\mathrm{CH}$ & 67.2 & $4.16, \mathrm{~m}$ & 67.2 & $4.00, \mathrm{~m}$ \\
\hline 5 & $\mathrm{CH}_{2}$ & 26.9 & $1.47, \mathrm{~m} ; 1.55, \mathrm{~m}$ & 25.8 & $1.48, \mathrm{~m}$ & 37 & $\mathrm{CH}_{2}$ & 30.7 & $\begin{array}{c}1.98, \mathrm{dt}, 12.0,3.6 \\
2.05, \mathrm{q}, 12.0\end{array}$ & 30.2 & $1.82, \mathrm{~m}$ \\
\hline 6 & $\mathrm{CH}_{2}$ & 38.6 & $1.46, \mathrm{~m} ; 1.52, \mathrm{~m}$ & 35.2 & $1.50, \mathrm{~m} ; 1.70, \mathrm{~m}$ & 38 & $\mathrm{CH}$ & 75.8 & $3.65^{\mathrm{b}}, \mathrm{m}$ & 75.5 & $3.55^{c}, \mathrm{~m}$ \\
\hline 7 & $\mathrm{CH}$ & 71.8 & $3.58, \mathrm{~m}$ & 80.3 & $4.39^{\mathrm{a}}, \mathrm{m}$ & 39 & $\mathrm{CH}$ & 74.5 & $3.75, \mathrm{~m}$ & 74.0 & $3.64, \mathrm{~m}$ \\
\hline 8 & $\mathrm{CH}_{2}$ & 38.6 & $1.46, \mathrm{~m} ; 1.52, \mathrm{~m}$ & 35.3 & $1.50, \mathrm{~m} ; 1.70, \mathrm{~m}$ & 40 & $\mathrm{CH}_{2}$ & 32.6 & $1.73, \mathrm{~m} ; 2.12, \mathrm{~m}$ & 32.1 & $1.60, \mathrm{~m} ; 2.0, \mathrm{~m}$ \\
\hline 9 & $\mathrm{CH}_{2}$ & 22.9 & $1.45, \mathrm{~m} ; 1.70, \mathrm{~m}$ & 21.9 & $1.49, \mathrm{~m} ; 1.60, \mathrm{~m}$ & 41 & $\mathrm{CH}_{2}$ & 27.9 & $2.27, \mathrm{~m}$ & 27.7 & $2.15, \mathrm{~m} ; 2.45, \mathrm{~m}$ \\
\hline 10 & $\mathrm{CH}_{2}$ & 38.6 & $1.46, \mathrm{~m} ; 1.52, \mathrm{~m}$ & 38.4 & $1.48, \mathrm{~m} ; 1.55, \mathrm{~m}$ & 42 & $\mathrm{C}^{2}$ & 152.0 & - & 151.3 & - \\
\hline 11 & $\mathrm{CH}^{-}$ & 68.6 & $4.18, \mathrm{~m}$ & 68.6 & $4.09, \mathrm{~m}$ & 43 & $\mathrm{CH}$ & 76.8 & $4.43, d, 8.6$ & 76.4 & $4.22, \mathrm{~d}, 8.8$ \\
\hline 12,14 & $\mathrm{CH}_{2}$ & 51.9 & $2.69, \mathrm{~m}$ & 51.6 & $2.65, \mathrm{~m}$ & 44 & $\mathrm{CH}$ & 75.3 & $3.54, \mathrm{~m}$ & 75.1 & $3.38, \mathrm{~m}$ \\
\hline 13 & $\mathrm{C}$ & 211.2 & - & 211.6 & - & 45 & $\mathrm{CH}$ & 70.6 & $4.25, \mathrm{dt}, 12.0,2.0$ & 70.4 & $4.07, \mathrm{~m}$ \\
\hline 15 & $\mathrm{CH}$ & 68.9 & $4.13, \mathrm{~m}$ & 68.8 & $4.07, \mathrm{~m}$ & 46 & $\mathrm{CH}_{2}$ & 31.9 & $\begin{array}{c}1.68, \mathrm{~m} ; 2.36, \mathrm{q} \\
12.0\end{array}$ & 31.5 & $1.60, \mathrm{~m} ; 2.12, \mathrm{~m}$ \\
\hline 16 & $\mathrm{CH}_{2}$ & 35.7 & $1.49, \mathrm{~m} ; 1.59, \mathrm{~m}$ & 35.5 & $1.40, \mathrm{~m} ; 1.50, \mathrm{~m}$ & 47 & $\mathrm{CH}$ & 67.3 & $4.21, \mathrm{dd}, 10.0,3.5$ & 69.2 & $4.07^{\mathrm{e}}, \mathrm{m}$ \\
\hline 17 & $\mathrm{CH}_{2}$ & 33.1 & $1.14, \mathrm{~m} ; 1.72, \mathrm{~m}$ & 33.0 & $1.15, \mathrm{~m} ; 1.62, \mathrm{~m}$ & 48 & $\mathrm{CH}$ & 68.6 & $4.33, \mathrm{~m}$ & 68.6 & $4.07^{\mathrm{e}}, \mathrm{m}$ \\
\hline 18 & $\mathrm{CH}_{2}$ & 30.6 & $1.76, \mathrm{~m}$ & 30.2 & $1.70, \mathrm{~m}$ & 49 & $\mathrm{CH}$ & 80.7 & $4.02, \mathrm{dd}, 10.0,1.5$ & 80.4 & $3.78 \mathrm{~m}$ \\
\hline 19 & $\mathrm{CH}_{2}$ & 41.3 & $1.47, \mathrm{~m} ; 1.55, \mathrm{~m}$ & 41.8 & $1.40, \mathrm{~m} ; 1.50, \mathrm{~m}$ & 50 & $\mathrm{CH}$ & 72.0 & $4.22, \mathrm{~m}$ & 71.9 & $3.99^{d}, m$ \\
\hline 20 & $\mathrm{CH}$ & 73.3 & $3.65^{\mathrm{b}}, \mathrm{m}$ & 73.3 & $3.55^{c}, \mathrm{~m}$ & 51 & $\mathrm{CH}$ & 74.2 & $4.62, \mathrm{dd}, 10.0,1.5$ & 74.1 & $4.39^{a}, \mathrm{~m}$ \\
\hline 21 & $\mathrm{CH}$ & 72.6 & $3.69, \mathrm{~m}$ & 72.6 & $3.5, \mathrm{~m}$ & 52 & $\mathrm{CH}$ & 129.1 & $5.79, \mathrm{dd}, 15.5,7.0$ & 128.1 & $5.63, \mathrm{dd}, 15.0,7.5$ \\
\hline 22 & $\mathrm{CH}_{2}$ & 38.7 & $1.57, \mathrm{~m} ; 1.88, \mathrm{~m}$ & 38.3 & $1.40, \mathrm{~m} ; 1.50, \mathrm{~m}$ & 53 & $\mathrm{CH}$ & 135.3 & $5.85, \mathrm{dt}, 15.5,5.7$ & 135.6 & $5.82, \mathrm{dt}, 15.0,6.5$ \\
\hline 23 & $\mathrm{CH}_{2}$ & 31.3 & $2.40, \mathrm{~m}$ & 31.0 & $2.18, \mathrm{~m}$ & 54 & $\mathrm{CH}_{2}$ & 34.6 & $1.99, \mathrm{~m}$ & 33.2 & $2.10, \mathrm{~m}$ \\
\hline 24 & $\mathrm{CH}$ & 77.2 & $3.57, \mathrm{~m}$ & 77.2 & $3.39, \mathrm{~m}$ & 55 & $\mathrm{CH}_{2}$ & 29.9 & $1.30, \mathrm{~m}$ & 30.8 & $1.44, \mathrm{~m}$ \\
\hline 25 & $\mathrm{CH}$ & 72.8 & $3.86, \mathrm{~m}$ & 72.5 & $3.71, \mathrm{~m}$ & $56-62$ & $\mathrm{CH}_{2}$ & $30.1-30.8$ & $1.21-1.30, \mathrm{~m}$ & $30.0-30.6$ & $1.33-1.35, \mathrm{~m}$ \\
\hline 26 & $\mathrm{CH}_{2}$ & 41.9 & $1.65, \mathrm{~m} ; 2.16, \mathrm{~m}$ & 41.6 & $1.56,2.02$ & 63 & $\mathrm{CH}_{2}$ & 34.6 & $1.97, \mathrm{~m}$ & 33.4 & $2.08, \mathrm{~m}$ \\
\hline 27 & $\mathrm{CH}$ & 71.8 & $4.00, \mathrm{~m}$ & 71.4 & $3.90, \mathrm{~m}$ & 64 & $\mathrm{CH}$ & 140.1 & $5.77, \mathrm{~m}$ & 135.8 & $5.81, \mathrm{~m}$ \\
\hline 28 & $\mathrm{CH}_{2}$ & 36.9 & $1.67, \mathrm{~m}$ & 36.7 & $1.63, \mathrm{~m} ; 1.71, \mathrm{~m}$ & 65 & $\mathrm{CH}_{2}$ & 115.0 & 4.91, brd, 11.0; & 114.3 & 4.94, brd, 10.7; \\
\hline 27 & $\mathrm{CH}$ & 71.8 & $4.00, \mathrm{~m}$ & 71.4 & $3.90, \mathrm{~m}$ & 64 & $\mathrm{CH}$ & 140.1 & 4.97, brd, 17.0 & 135.8 & $5.01^{\mathrm{f}}$ \\
\hline 29 & $\mathrm{CH}_{2}$ & 36.4 & $2.12, \mathrm{~m} ; 2.27, \mathrm{~m}$ & 36.4 & $2.16, \mathrm{~m} ; 2.24, \mathrm{~m}$ & 66 & $\mathrm{CH}_{3}$ & 21.3 & $0.91, d, 7.0$ & 20.8 & $0.99, d, 6.9$ \\
\hline 30 & $\mathrm{C}$ & 138.4 & - & 139.2 & - & 67 & $\mathrm{CH}_{3}$ & 14.2 & $1.05, d, 6.5$ & 13.7 & $0.97, d, 7.0$ \\
\hline 31 & $\mathrm{CH}$ & 126.1 & $5.66, d, 9.0$ & 126.0 & $5.52, d, 8.5$ & 68 & $\mathrm{CH}_{3}$ & 17.4 & $1.75, \mathrm{~s}$ & 17.0 & $1.78, \mathrm{~s}$ \\
\hline 32 & $\mathrm{CH}$ & 67.5 & $4.76, \mathrm{dd}, 9.0,2.0$ & 67.6 & $4.58, \mathrm{dd}, 8.5,1.5$ & 69 & $\mathrm{CH}_{2}$ & 113.0 & $5.03, \mathrm{~s} ; 5.17, \mathrm{~s}$ & 112.7 & $5.01^{\mathrm{f}}, \mathrm{s} ; 5.10, \mathrm{~s}$ \\
\hline
\end{tabular}

a-f Overlapping signals with the same superscript letter. 


\section{Materials and Methods}

\subsection{General Experimental Procedures}

Optical rotations were measured on a Jasco P2000 digital polarimeter (Jasco, Cremella, Italy). UV spectra were acquired on a Jasco V-650 spectrophotometer, NMR spectra were recorded on a Bruker Avance DRX 600 (Bruker, Milan, Italy) equipped with a cryoprobe operating at $600 \mathrm{MHz}$ for protons. Chemical shift values are reported in ppm $(\delta)$ and referenced to internal signals of residual protons $\left(\mathrm{CD}_{3} \mathrm{OD}{ }^{1} \mathrm{H} \delta 3.34,{ }^{13} \mathrm{C} 49.0 \mathrm{ppm}\right)$. High-resolution mass spectra were acquired on a Q-Exactive Hybrid Quadrupole-Orbitrap mass spectrometer (Thermo Scientific, Milan, Italy); HPLC analyses have been performed on a Jasco system (PU-2089 Plus-quaternary gradient pump equipped with a Jasco MD-2018 Plus photodiode array detector). $\left[1-{ }^{13} \mathrm{C}\right]$-acetate, $\left[2-{ }^{13} \mathrm{C}\right]$-acetate and $\left[1,2-{ }^{13} \mathrm{C}_{2}\right]$-acetate, $\left[1-{ }^{13} \mathrm{C}\right]$-glycolate (all sodium salts), and salicylhydroxamic acid (SHAM) were obtained from Sigma Aldrich (Milan, Italy). Solvents were purchased from VWR (Milan, Italy) and were HPLC-grade.

\subsection{Biological Material}

Amphidinium carterae was isolated in June 2012 from a sample of Dyctiota dichotoma collected from Lake Fusaro, near Naples, Italy. Once transferred to the lab, kept in containers filled with seawater, the macroalgae $D$. dichotoma were shaken vigorously to enhance epiphyte detachment. Zooplankton and larger animals were removed by gentle filtering onto a $30 \mu \mathrm{m}$ nylon mesh. Seawater subsamples were then transferred to Petri dishes. The dinoflagellate cells were isolated by capillary pipettes and initially grown in multiwell plates filled with $\mathrm{K}$ medium [33]. Species identification was performed by FEM2-Ambiente Srl (Milan, Italy) and the strain is available in our lab, coded as ICB-BCL0018.

Amphidinium carterae was cultured in $\mathrm{K}$ medium at $22.0 \pm 0.5{ }^{\circ} \mathrm{C}$, under a $14: 10 \mathrm{~h}$ light:dark regime and at $100 \mu \mathrm{mol} \mathrm{m} \mathrm{m}^{-2} \mathrm{~s}^{-1}$. The cells were mass-cultivated in four sterile 1.8 $\mathrm{L}$ glass Fernbach bottles, each containing $1 \mathrm{~L}$ of culture. The initial cell density was around 8000 cells $/ \mathrm{mL}$. During the exponential phase, each subculture was halved, and refreshed with half a liter of K medium. In the stationary phase (final cell density: 230,000 cells $/ \mathrm{mL}$ ), the eight liters of culture were harvested in a swing-out centrifuge (Allegra 12-XR, Beckman Coulter, Milan, Italy), for $10 \mathrm{~min}$ at $4{ }^{\circ} \mathrm{C}$ at $2300 \times g$. The cell pellet was stored at $-80{ }^{\circ} \mathrm{C}$ until analysis.

\subsection{Extraction and Isolation of Amphidinols $\mathbf{1}$ and $\mathbf{2}$}

The cell pellet of $A$. carterae (wet weight $1.9 \mathrm{~g})$ was extracted with methanol $(3 \times 10 \mathrm{~mL})$ by sonication and centrifuged to remove cell debris. The methanol phase was filtered through paper and concentrated under vacuum. The crude extract $(180 \mathrm{mg})$ was fractionated on a Chromabond C-18 Hydra column (5 g of dry resin ) (Macherey-Nagel, Düren, Germany) by using the following stepwise elution protocol: A (100\% $\left.\mathrm{H}_{2} \mathrm{O}, 40 \mathrm{~mL}\right), \mathrm{B}(25 \% \mathrm{MeOH}, 40 \mathrm{~mL}), \mathrm{C}(50 \% \mathrm{MeOH}, 40 \mathrm{~mL})$, $\mathrm{D}(75 \% \mathrm{MeOH}, 40 \mathrm{~mL})$, and $\mathrm{E}(100 \% \mathrm{MeOH}, 80 \mathrm{~mL})$. Fraction D (6.4 mg) was further purified on a RP-HPLC column (C18-Luna, Phenomenex, $5 \mu \mathrm{m} 100 \mathrm{~A}, 250 \times 10 \mathrm{~mm}$ ) by a MeOH/ $\mathrm{H}_{2} \mathrm{O}$ initial gradient from $65 \%$ to $80 \%$ of $\mathrm{MeOH}$ for $20 \mathrm{~min}$, followed by a gradient to $100 \% \mathrm{MeOH}$ for $15 \mathrm{~min}$ (flow $3 \mathrm{~mL} / \mathrm{min}$ ). UV absorbance at $210 \mathrm{~nm}$ was used for peak detection. Pure compound 1 (1.6 mg) was eluted at $\mathrm{Rt}=23 \mathrm{~min}$. Fraction C (2.5 mg) was purified by HPLC, as above, affording $1.0 \mathrm{mg}$ of pure compound 2 (Rt $=8 \mathrm{~min})$.

Amphidinol A (1). Pale yellow amorphous solid. $[\alpha]_{25}{ }^{\mathrm{D}}+3(c 0.14, \mathrm{MeOH}) ; \mathrm{UV}(\mathrm{MeOH}) \lambda_{\max }(\log \varepsilon)$ 210 (4.75) nm; NMR see Table 1. HR-ESIMS $m / z 1361.8532[\mathrm{M}+\mathrm{Na}]^{+}$(calcd for $\mathrm{C}_{69} \mathrm{H}_{126} \mathrm{O}_{24} \mathrm{Na}^{+}$, 1361.8531).

Amphidinol B (2). Pale yellow amorphous solid. $[\alpha]_{25}{ }^{\mathrm{D}}+1(c 0.16, \mathrm{MeOH}) ; \mathrm{UV}(\mathrm{MeOH}) \lambda_{\max }$ $(\log \varepsilon) 210$ (4.30) nm; NMR Data see Table 1. HR-ESIMS [M-H] ${ }^{-} m / z 1417.8187$ (calcd for $\mathrm{C}_{69} \mathrm{H}_{125} \mathrm{SO}_{27}{ }^{-}$1417.8134); [M-H+2Na] ${ }^{+} m / z 1463.7912$ (calcd for $\mathrm{C}_{69} \mathrm{H}_{125} \mathrm{SO}_{27} \mathrm{Na}_{2}{ }^{+} 1463.7919$ ). 


\subsection{Biosynthetic Experiments}

\subsubsection{Control}

The culture used as the control of the biosynthetic experiments was grown in a sterile $1.8 \mathrm{~L}$ glass Fernbach bottle, containing $1.5 \mathrm{~L}$ of culture medium with antibiotics $(35 \mu \mathrm{g} / \mathrm{mL}$ of Penicillin $\mathrm{G}$ and $50 \mathrm{U} / \mathrm{mL}$ of streptomycin) added together with inoculation. The initial cell density was around 8000 cells $/ \mathrm{mL}$. Cells were harvested after three weeks in their stationary phase (with a final cell density of 250,000 cells $/ \mathrm{mL}$ ) by a swing-out centrifuge Allegra 12-XR (Beckman Coulter, Milan, Italy), for $10 \mathrm{~min}$ at $4{ }^{\circ} \mathrm{C}$ at $2300 \mathrm{~g}$. The cell pellet (wet weight $400 \mathrm{mg}$ ) was stored at $-80{ }^{\circ} \mathrm{C}$ before chemical analysis.

\subsubsection{Feeding Experiments with Labelled Acetate}

Experiments with $\left[1-{ }^{13} \mathrm{C}\right]$-Acetate

$\left[1-{ }^{13} \mathrm{C}\right]$-acetate $(0.6 \mathrm{mM})$ was added to culture medium $(1.5 \mathrm{~L}$ of $\mathrm{K}$ medium in $5 \times 1.8 \mathrm{~L}$ glass Fernbach bottles) together with antibiotics and inoculated as above. After three weeks, at the stationary phase, the cell density reached 200,000 cells $/ \mathrm{mL}$ and the culture was harvested as above. The cell pellets (wet weight $1.9 \mathrm{~g}$ ) was extracted with $\mathrm{MeOH}$ affording $110 \mathrm{mg}$ of raw extract which was purified as previously described. Briefly, the extract was loaded onto a Chromabond C18 Hydra cartridge ( $6 \mathrm{~mL} / 500 \mathrm{mg}$ ) and eluted as indicated above ( $8 \mathrm{~mL}$ each step). Further purification by RP-HPLC of the fraction $\mathrm{D}(7.2 \mathrm{mg})$ led to the isolation of $2 \mathrm{mg}$ of labelled amphidinol A (1).

Experiments with $\left[2-{ }^{13} \mathrm{C}\right]$-Acetate

$\left[2-{ }^{13} \mathrm{C}\right]$-acetate $(0.6 \mathrm{mM})$ was added to culture medium $(1.5 \mathrm{~L}$ of $\mathrm{K}$ medium in $1.8 \mathrm{~L}$ glass Fernbach bottle) together with antibiotics and inoculated as above. After 21 days, at the stationary phase cell density reached 71,000 cells $/ \mathrm{mL}$ and the culture was harvested as above. The cell pellets (wet weight $270 \mathrm{mg}$ ) was extracted with $\mathrm{MeOH}$ affording $15.5 \mathrm{mg}$ of raw extract and purified as previously described using a cartridge of Chromabond C18 Hydra $(6 \mathrm{~mL} / 500 \mathrm{mg})$ and $8 \mathrm{ml}$ of solvent for the stepwise elution. Further purification by RP-HPLC of the fraction D eluted with 75\% MeOH $(1.3 \mathrm{mg})$ led to the isolation of $<0.1 \mathrm{mg}$ of labeled polyketide 1 .

Experiments with $\left[1,2-{ }^{13} \mathrm{C}_{2}\right]$-Acetate

$\left[1,2-{ }^{13} \mathrm{C}_{2}\right]$-acetate $(0.6 \mathrm{mM})$ was added to culture medium $(1.5 \mathrm{~L}$ of $\mathrm{K}$ medium in $5 \times 1.8 \mathrm{~L}$ glass Fernbach bottles) together with antibiotics and inoculated as above. After 21 days, at the stationary phase, the cell density reached 84,000 cells $/ \mathrm{mL}$ and the culture was harvested as above. The cell pellet (wet weight $270 \mathrm{mg}$ ) was extracted with $\mathrm{MeOH}$, affording $19.5 \mathrm{mg}$ of raw extract and purified as previously described using a cartridge of Chromabond C18 Hydra $(6 \mathrm{~mL} / 500 \mathrm{mg})$ and $8 \mathrm{~mL}$ of solvent for the stepwise elution. Further purification by RP-HPLC of the fraction eluted with $75 \% \mathrm{MeOH}$ $(1.6 \mathrm{mg})$ led to the isolation of $0.2 \mathrm{mg}$ of labeled product $\mathbf{1}$.

\subsubsection{Feeding Experiments with Labelled Glycolate}

Experiments with $\left[1-{ }^{13} \mathrm{C}\right]-$ Glycolate

Two sterile $1.8 \mathrm{~L}$ glass Fernbach bottles, containing $1.5 \mathrm{~L}$ of inoculated culture treated with antibiotics were grown as described above with $0.42 \mathrm{mM}\left[1-{ }^{13} \mathrm{C}\right]$-glycolate. After 21 days, when the final cell density was around 130,000 cells $/ \mathrm{mL}$, the culture was centrifuged and the humid pellet $(834 \mathrm{mg}$ ) was extracted with $\mathrm{MeOH}$ affording $82.7 \mathrm{mg}$ of extract. Two step fractionation by C18 Hydra resin $(2.3 \mathrm{~g})$ followed by RP-HPLC, led to $1 \mathrm{mg}$ of pure labelled product 1. 
Experiments with $\left[1-{ }^{13} \mathrm{C}\right]$-Glycolate/Salicylhydroxamic Acid (SHAM)

$\left[1-{ }^{13} \mathrm{C}\right]$-glycolate $(0.42 \mathrm{mM})$, SHAM $(0.5 \mathrm{mM})$, and antibiotics $(35 \mu \mathrm{g} / \mathrm{mL}$ Penicillin $\mathrm{G}$ and $50 \mathrm{U} / \mathrm{mL}$ streptomycin) were added simultaneously with inoculation. The cell culture $(150 \mathrm{~mL}, 8000$ cells $/ \mathrm{mL})$ was harvested after three weeks $(356,000$ cells $/ \mathrm{mL})$. A second algal culture control with $0.5 \mathrm{mM}$ of inhibitor and without labelled glycolate was grown under the same conditions.

The cell pellet $(119 \mathrm{mg})$ from the experiment with labeled glycolate and SHAM was extracted with $\mathrm{MeOH}$ to obtain $11.9 \mathrm{mg}$ of raw material. By fractionation with a C18 Hydra Chromabond cartridge $(3 \mathrm{~mL} / 200 \mathrm{mg})$ with the usual elution gradient $(5 \mathrm{~mL}$ for each solvent) two enriched fractions $\mathrm{C}(0.5 \mathrm{mg})$ and $\mathrm{D}(0.7 \mathrm{mg})$ were obtained. Further purification by HPLC, as described above, led to the isolation of labelled amphidinol A $(\mathbf{1}, 0.1 \mathrm{mg})$ and B $(\mathbf{2},<0.1 \mathrm{mg})$. The polyketide profile in the control culture with SHAM was unaffected by the presence of the inhibitor.

\subsection{Antifungal Test}

Antifungal activity was tested against Candida albicans (ATCC90028) with the broth microdilution liquid growth inhibition method in sterile 96-well plates. The final fungal cell concentration was $1 \times 10^{4} \mathrm{CFU} / \mathrm{mL}$. Plates were incubated at $37{ }^{\circ} \mathrm{C}$ for $48 \mathrm{~h}$. Results have been reported as MIC (minimum inhibitory concentration) in $\mu \mathrm{g} / \mathrm{mL}$.

Supplementary Materials: The following are available online at www.mdpi.com/1660-3397/15/6/157/s1, Figures S1-S20: NMR data, Figures S21-S23: ESIMS data.

Acknowledgments: Authors are grateful to Pierpaolo Botte for collecting biological material and to Servizio NMR at ICB-CNR (Pozzuoli, Naples, Italy) through the person of Dominique Melck for recording spectra. Daniela Jabes (NeED Pharmaceuticals Srl, Milan, Italy) is also acknowledged for antifungal tests. Funding was provided by the National Research Council of Italy (CNR) (project number DCM.AD003.051 "Natural Products and their biomedical and environmental applications") and PON01_00117.

Author Contributions: Adele Cutignano conceived and designed the study; Adele Cutignano, Genoveffa Nuzzo and Angela Sardo performed the experiments; Adele Cutignano and Genoveffa Nuzzo analyzed the data; Angelo Fontana contributed materials/reagents and critically revised the manuscript; and Adele Cutignano wrote the paper. All authors read, revised, and approved the final document.

Conflicts of Interest: The authors declare no conflict of interest.

\section{References}

1. Romano, G.; Costantini, M.; Sansone, C.; Lauritano, C.; Ruocco, N.; Ianora, A. Marine microorganisms as a promising and sustainible source of bioactive molecules. Mar. Environ. Res. 2016. [CrossRef]

2. Cutignano, A.; Nuzzo, G.; Ianora, A.; Luongo, E.; Romano, G.; Gallo, C.; Sansone, C.; Aprea, S.; Mancini, F.; D'Oro, U.; et al. Development and application of a novel SPE-method for bioassay-guided fractionation of marine extracts. Mar. Drugs 2015, 13, 5736-5749. [CrossRef] [PubMed]

3. Satake, M.; Murata, M.; Yasumoto, T.; Fujita, T.; Naoki, H. Amphidinol, a polyhydroxypolyene antifungal agent with an unprecedented structure, from a marine dinoflagellate, Amphidinium klebsii. J. Am. Chem. Soc. 1991, 113, 9859-9861. [CrossRef]

4. Paul, G.K.; Matsumori, N.; Murata, M.; Tachibana, K. Isolation and chemical structure of amphidinol 2, a potent hemolytic compound from marine dinoflagellate Amphidinium klebsii. Tetrahedron Lett. 1995, 36, 6279-6282.

5. Paul, G.K.; Matsumori, N.; Konoki, K.; Sasaki, M.; Murata, M.; Tachibana, K. Harmful and Toxic Algal Blooms; Yasumoto, T., Oshima, Y., Tukuyo, Y., Eds.; Intergovernmental Oceanographic Commission of UNESCO: Paris, France, 1996; pp. 503-506.

6. Paul, G.K.; Matsumori, N.; Konoki, K.; Murata, M.; Tachibana, K. Chemical structures of amphidinols 5 and 6 isolated from marine dinoflagellate Amphidinium klebsii and their cholesterol-dependent membrane disruption. J. Mar. Biotechnol. 1997, 5, 124-128.

7. Houdai, T.; Matsuoka, S.; Murata, M.; Satake, M.; Ota, S.; Oshima, Y.; Rhodes, L.L. Acetate labeling patterns of dinoflagellate polyketides, amphidinols 2, 3 and 4. Tetrahedron 2001, 57, 5551-5555. [CrossRef] 
8. Morsy, N.; Matsuoka, S.; Houndai, T.; Matsumori, N.; Adachi, S.; Murata, M.; Iwashita, T.; Fujita, T. Isolation and structure elucidation of a new amphidinol with truncated polyhydroxyl chain from Amphidinium klebsii. Tetrahedron 2005, 61, 8606-8610. [CrossRef]

9. Echigoya, R.; Rhodes, L.; Oshima, Y.; Satake, M. The structures of five new antifungal and hemolytic amphidinol analogs from Amphidinium carterae collected in New Zealand. Harmful Algae 2005, 4, 383-389. [CrossRef]

10. Morsy, N.; Houdai, T.; Matsuoka, S.; Matsumori, N.; Adachi, S.; Oishi, T.; Murata, M.; Iwashita, T.; Fujita, T. Structures of new amphidinols with truncated polyhydroxyl chain and their membrane-permeabilizing activity. Bioorg. Med. Chem. 2006, 14, 6548-6554. [CrossRef] [PubMed]

11. Meng, Y.; Van Wagoner, R.M.; Misner, I.; Tomas, C.; Wright, J.L.C. Structure and biosynthesis of amphidinol 17, a hemolytic compound from Amphidinium carterae. J. Nat. Prod. 2010, 73, 409-415. [CrossRef] [PubMed]

12. Huang, S.; Kuo, C.; Lin, Y.; Chen, Y.; Lu, C.; Carteraol, E. a potent polyhydroxyl ichthyotoxin from the dinoflagellate Amphidinium carterae. Tetrahedron Lett. 2009, 50, 2512-2515. [CrossRef]

13. Huang, X.; Zhao, D.; Guo, Y.; Wu, H.; Lin, L.; Wang, Z.; Ding, J.; Lin, Y. Lingshuiol, a novel polyhydroxyl compound with strongly cytotoxic activity from the marine dinoflagellate Amphidinium sp. Biorg. Med. Chem. Lett. 2004, 14, 3117-3120.

14. Huang, X.; Zhao, D.; Guo, Y.; Wu, H.; Trivellone, E.; Cimino, G. Lingshuiols A and B, two new polyhydroxy compounds from the Chinese marine dinoflagellate Amphidinium sp. Tetrahedron Lett. 2004, 45, 5501-5504. [CrossRef]

15. Hanif, N.; Ohno, O.; Kitamura, M.; Yamada, K.; Uemura, D. Symbiopolyol, a VCAM-1 inhibitor from a symbiotic dinoflagellate of the jellyfish Mastigias papua. J. Nat. Prod 2010, 73, 1318-1322. [CrossRef] [PubMed]

16. Washisa, K.; Koyama, T.; Yamada, K.; Kita, M.; Uemura, D. Karatungiols A and B, two novel antimicrobial polyol compounds, from the symbiotic marine dinoflagellate Amphidinium sp. Tetrahedron Lett. 2006, 47, 2521-2525. [CrossRef]

17. Van Wagoner, R.; Deeds, J.R.; Satake, M.; Ribeiro, A.A.; Place, A.R.; Wright, J.L.C. Isolation and characterization of karlotoxin 1, a new amphipathic toxin from Karlodinium veneficum. Tetrahedron Lett. 2008, 49, 6457-6461. [CrossRef] [PubMed]

18. Peng, J.; Place, A.R.; Yoshida, W.; Anklin, C.; Hamann, M.T. Structure and absolute configuration of karlotoxin-2, an ichthyotoxin from the marine dinoflagellate Karlodinium veneficum. J. Am. Chem. Soc. 2010, 132, 3277-3279. [CrossRef] [PubMed]

19. Kubota, T.; Takahashi, A.; Tsuda, M.; Kobayashi, J. Luteophanol D, new polyhydroxyl metabolite from marine dinoflagellate Amphidinium sp. Mar. Drugs 2005, 3, 113-118. [CrossRef]

20. Inuzuka, T.; Yamamoto, Y.; Yamada, K.; Uemura, D. Amdigenol A, a long carbon-backbone polyol compound, produced by the marine dinoflagellate Amphidinium sp. Tetrahedron Lett. 2012, 53, 239-242. [CrossRef]

21. Nuzzo, G.; Cutignano, A.; Sardo, A.; Fontana, A. Antifungal amphidinol 18 and its 7-sulfate derivative from the marine dinoflagellate Amphidinium carterae. J. Nat. Prod. 2014, 77, 1524-1527. [CrossRef] [PubMed]

22. Swasono, R.T.; Mouri, R.; Morsy, N.; Matsumori, N.; Oishi, T.; Murata, M. Sterol effect on interaction between amphidinol 3 and liposomal membrane as evidenced by surface plasmon resonance. Bioorg Med. Chem. Lett. 2010, 20, 2215-2218. [CrossRef] [PubMed]

23. Houdai, T.; Matsuoka, S.; Morsy, N.; Matsumori, N.; Satake, M.; Murata, M. Hairpin conformation of amphidinols possibly accounting for potent membrane permeabilizing activities. Tetrahedron 2005, 61, 2795-2802. [CrossRef]

24. Needham, J.; McLachlan, J.L.; Walter, J.A.; Wright, J.L. Biosynthetic origin of C-37 and C-38 in the polyether toxins okadaic acid and dinophysistoxin-1. J. Chem. Soc. Chem. Comm. 1994, 22, 2599-2600. [CrossRef]

25. Kellman, R.; Stüken, A.; Orr, R.J.S.; Svendsen, H.M.; Jakobsen, K.S. Biosynthesis and molecular genetics of polyketides in marine dinoflagellates. Mar. Drugs 2010, 8, 1011-1048. [CrossRef] [PubMed]

26. Xiang, L.; Kalaitzis, J.A.; Moore, B.S. EncM, a versatile enterocyn biosynthetic enzyme involved in Favorskii oxidative rearrangement, aldol condensation, and heterocycle-forming reaction. Proc. Natl. Acad. Sci. USA 2004, 101, 15609-15614. [CrossRef] [PubMed]

27. Julien, B.; Tian, Z.Q.; Reid, R.; Reeves, C.D. Analysis of the ambruticin and jerangolid gene clusters of Sorangium cellulosum reveals unusual mechanism of polyketide biosynthesis. Chem. Biol. 2006, 13, 1277-1286. [CrossRef] [PubMed] 
28. Simpson, T.J.; Holker, J.S.E. The biosynthesis of a pyrone metabolite of Aspergillus melleus. An application of long-range ${ }^{13} \mathrm{C}-{ }^{13} \mathrm{C}$ coupling constants. Tetrahedron Lett. 1975, 16, 4693-4696. [CrossRef]

29. Wright, J.L.C.; Hu, T.; McLachlan, J.L.; Needham, J.; Walter, J.A. Confirmation of a polyketide pathway, proof of a Bayer-Villiger oxidation step, and evidence for an unusual carbon deletion process. J. Am. Chem. Soc. 1996, 118, 8757-8758. [CrossRef]

30. Kisaki, T.; Tolbert, N.E. Glycolate and glyoxylate metabolism by isolated peroxisomes or chloroplasts. Plant Physiol. 1969, 44, 242-250. [CrossRef] [PubMed]

31. Goyal, A.; Tolbert, N.E. Association of glycolate oxidation with photosynthetic electron transport in plant and algal chloroplasts. Proc. Natl. Acad. Sci. USA 1996, 93, 3319-3324. [CrossRef] [PubMed]

32. Goyal, A. Glycolate metabolism in algal chloroplasts: Inhibition by salicylhydroxamic acid (SHAM). Physiol. Plant. 2002, 116, 264-270. [CrossRef] [PubMed]

33. Keller, D.M.; Selvin, C.R.; Claus, W.; Guillard, R.R. Media for the culture of oceanic ultraphytoplankton. J. Phycol. 1987, 23, 633-638. [CrossRef]

(C) 2017 by the authors. Licensee MDPI, Basel, Switzerland. This article is an open access article distributed under the terms and conditions of the Creative Commons Attribution (CC BY) license (http:// creativecommons.org/licenses/by/4.0/). 